Jurnal Wacana Kesehatan

Volume 6, Nomor 1, Juli 2021

e-ISSN 2544-6251

https://doi.org/10.52822/jwk.v6i1.172

\title{
BERMAIN (PUZZLE) TERHADAP KECEMASAN ANAK USIA PRASEKOLAH YANG MENGALAMI HOSPITALISASI
}

\section{PLAY (PUZZLE) AGAINST PRE-SCHOOL AGE CHILDREN WHO ARE HOSPITALIZED}

\author{
Andri Yulianto ${ }^{1}$, Idayati ${ }^{2}$, Senja Atika Sari ${ }^{3}$ \\ Universitas Muhammadiyah Pringsewu ${ }^{12}$ Akper Dharma Wacana ${ }^{3}$ \\ andrri.yuliianto@gmail.com ${ }^{1}$,idayati17.bangsawan@gmail.com ${ }^{2}$
}

\begin{abstract}
ABSTRAK
Hospitalisasi merupakan bagian yang dimana anak harus beradaptas dengan lingkungan yang baru, mengurangi perpisahan dengan keluarga, nyeri ditubuh akibat dari traumatic. Hal ini dapat mengakibatkan anak menjadi ketkutan, merasa terancam, gelisah dan cemas. Penelitian ini bertujuan untuk diketahui pengaruh terapi bermain (puzzle) terhadap kecemasan anak usia prasekolah (4-6 tahun) yang mengalami hospitalisasi di ruang anak RSUD Pringsewu. Penelitian kuantitatif dengan pendekatan crossectional rancangan penelitian eksperimen semu. Populasi dalam penelitian ini adalah anak yang berusia 4- 6 tahun yang dirawat di ruang anak RSUD Pringsewu dengan jumlah populasi 16 responden,Teknik sampling yang digunakan adalah total sampling. Instrument yang digunakan dalam penelitian ini adalah kuesioner dan lembar SOP Terapi Bermain. Hasil penelitian menunjukkan diketahui mean tingkat kecemasan akibat hospitaliisasi pada anak usia prasekolah sebelum pemberian intervensi 20,94 dengan tingkat kecemasan minimal 16 dan maximal 26 poin. Dan diketahui mean tingkat kecemasan akibat hospitalisasi pada anak usia prasekolah setelah pemberian intervensi 13,38 dengan tingkat kecemasan minimal 8 dan maximal 19 poin. Sehingga hasil analisis uji bivariat pada $r$ tabel 12,638 dan $r$ hitung 1,746. Selanjutnya berdasarkan hasil uji statistik didapatkan $p$-value $=0,000$ ( $\mathrm{p}$-value $<\alpha=0,05$ ) yang berarti ada pengaruh terapi bermain terhadap tingkat kecemasan akibat hospitalisasi pada anak usia prasekolah di ruang anak. Saran menyediakan suatu ruangan bermain anak disertai Standar Operasional Pelaksanaan tindakan yang akan dilakukan sehingga dapat meningkatkan keterampilan petugas dalam melaksanakan asuhan / pelayanan kepada pasien.
\end{abstract}

Kata Kunci : Bermain Puzzle, Kecemasan Hospitalisasi

\begin{abstract}
Hospitalization is a part where children have to adapt to a new environment, reduce separation from family, body pain due to trauma. This can cause children to become frightened, feel threatened, restless and anxious. This study aims to determine the effect of play therapy (puzzle) on the anxiety of preschool children (4-6 years) who are hospitalized in the children's room at Pringsewu Hospital. Quantitative research with a cross-sectional approach quasi-experimental research design. The population in this study were children aged 4-6 years who were treated in the children's room at Pringsewu Hospital with a population of 16 respondents. The sampling technique used was total sampling. The instruments used in this study were questionnaires and Play Therapy SOP sheets. The results showed that the mean level of anxiety due to hospitalization in preschool children before the intervention was 20.94 with a minimum anxiety level of 16 and a maximum of 26 points. And it is known that the mean level of anxiety due to hospitalization in preschool age children after the intervention is 13.38 with a minimum anxiety level of 8 and a maximum of 19 points. So that the results of the bivariate test analysis on $r$ table 12.638 and $r$ count 1.746 . Furthermore, based on the results of statistical tests obtained p-value $=0.000$ (p-value $<=0.05$ ) which means that there is an effect of play therapy on the level of anxiety due to hospitalization in preschool-aged children in the nursery. Suggestions provide a children's play room accompanied by Operational Standards for the implementation of actions to be taken so as to improve the skills of officers in carrying out care / services to patients.
\end{abstract}

Keywords: Puzzle Play, Hospitalization Anxiety 


\section{PENDAHULUAN}

Anak dalam kondisi sakit memungkinkan untuk dilakukan perawatan di rumah sakit. Anak mengalami yang mengalami Hospitalisasi disebabkan akibat dampak perpisahan dengan keluarga, nyeri di tubuh karena perlukaan, otonomi berkurang, dan harus beradaptasi dengan lingkungan baru. Hal ini membuat anak akan merasakan ketakutan, sepi, merasa terancam, cemas dan gelisah. Perubahan status kesehatan dan perbedaan lingkungan dan kebiasaan kegiatan mengakibatkan stres dan cemas yang dialami anak oleh karena adanya pada saat sehat maupun anak yang saat sakit, atau adanya perpisahan dengan keluarga saat masa perawatan ${ }^{1}$.

Suatu proses dimana anak dalam suatu alasan yang berencana atau darurat, mengharuskan anak untuk tinggal di rumah sakit, menjalani terapi dan perawatan hingga pemulangan pulang ke rumah merupakan Hospitalisasi. Pada anak reaksi hospitalisasi bersifat subyektif dan bergantung pada tahapan usia perkembangan anak, sistem yang tersedia, pengalaman dirawat sebelumnya, dan kemampuan koping yang dimiliki anak. Orang tua dan Anak prasekolah dapat mengalami berbagai kejadian yang menurut beberapa penelitian ditunjukkan dengan rasa stress yang penuh dan pengalaman yang sangat menyakitkan. $^{2}$

Anak yang menjalani hospitalisasi karena prosedur pembedahan sehingga anak yang mengalami stres dan kecemasan di Amerika Serikat, dari 5 juta diperkirakan lebih dari 50\% (Kain, et al, dalam Kaluas 2015). Di Mesir, dari 1445 pasien dengan cedera dunia terbuka tercatat sebanyak 476 anak-anak dalam kelompok usia 2 sampai dengan 16 tahun, ini berarti bahwa anak-anak di bawah usia 16 mewakili sekitar $28 \%$ dari total jumlahpasien korban. Kebanyakan pasien $(44,9 \%)$ berada pada kelompok usia 2 sampai dengan 6 tahun diikuti oleh kelompok remaja usia (11 sampai dengan 16 tahun) $(42,4 \%)^{2}$
Proporsi pemanfaatan rawat jalan menurut kelompok usia 0 sampai dengan 4 tahun sebesar $2,8 \%$, usia 5 sampai dengan 14 tahun sebanyak $1,4 \%$, usia 15 sampai dengan 24 tahun sekitar $2,1 \%$, usia 16 sampai dengan 21 tahun sebesar $8,14 \%$. Rata-rata anak yang menjalani rawat inap di rumah sakit di seluruh Indonesia adalah $2,8 \%$ dari total jumlah anak 82.666 orang lebih tinggi dari angka nasional yaitu $2,4 \%{ }^{3}$

Kecemasan terbesar pada anak usia prasekolah selama menjalani hospitalisasi adalah kecemasan terjadinya perlukaan pada bagian tubuhnya. Semua prosedur atau tindakan keperawatan baik yang menimbulkan nyeri maupun tidak dapat menyebabkan kecemasan anak prasekolah. Hal ini disebabkan karena keterbatasan pemahaman anak mengenai tubuh. Kecemasan seperti anak menangis diam-diam karena kepergian orang tua mereka, menolak makan, mengalami sulit tidur, tidak kooperatif terhadap petugas kesehatan saat dilakukan tindakan keperawatan dan sering bertanya tentang keadaan dirinya merupakan reaksi anak usia pra sekolah ${ }^{2}$

Dalam pelaksanaan perawatan yang akan diberikan respon anak terhadap hospitalisasi menimbulkan kendala, sehingga kendala tersebut menghambat proses penyembuhan. Sehingganya selama perawatan menyebabkan waktu perawatan yang lebih lama, bahkan akan mempercepat terjadinya komplikasikomplikasi. Upaya untuk mengatasi efek dari hospitalisasi pada anak adalah meminimalkan stressor, untuk meminimalkan efek negatif dari hospitalisasi anak membutuhkan perawatan yang sensitif dan kompeten. ${ }^{4}$ Salah satunya upaya yang dapat dilakukan untuk mengatasi hospitalisasi adalah dengan terapi bermain, pada anak usia prasekolah jenis permainan yang sesuai usianya adalah bermain game sederhana, permainan peran dan bermain puzzle atau bermain dengan puzzle.

Pemberian stimulasi bermain pada anak yang di rawat salah satunya dapat di bacakan buku 
cerita. ${ }^{6}$. Bermain Terapeutik merubah kecemasan anak pada saat pemberian tindakan merupakan bagian dari media yang lebih efisien. Anak-anak senang dengan bermain karena memang sangat menyenangkan. Suatu permainan terapeutik (therapeutic play), dimana sifat permainan terapeutik tersebut sebagai mekanisme perkembangan dan peristiwa yang kritis seperti hospitalisasi. Dan merupakan permainan yang sederhana, Permainan terapeutik atau bermain terapeutik ini terdiri dari aktivitas-aktivitas yang tergantung dengan kebutuhan perkembangan anak maupun lingkungan yang berorientasi untuk pengobatan dapat disampaikan dalam berbagai bentuk di antaranya adalah seni ekspresi atau kreatif, pertunjukan interaktif, permainan boneka atau puzzle dan lain-lain. Tujuan dalam bermain anak usia prasekolah pada dasarnya agar tidak merasa jenuh, memperoleh kesenangan serta dapat mengakibatkan melupakan kecemasan. Dengan melepaskan kecemasan bermain terapeutik diyakini memiliki efek healing atau penyembuhan sehingga menjadikan bermain berkembang menjadi sebuah metode terapi pada anak. Jenis permainan yang banyak dipilih pada anak usia prasekolah yang menggunakan kemampuan motorik (skill play) yaitu seperti menggambar manic manic ukuran besar, lilin yang dapat dibentuk, dan puzzle. ${ }^{7}$

Puzzle merupakan suatu metode permainan dengan menggunakan ketekunan dan kesabaran dalam merangkainya. Tujuan metode bermain puzzle ini dipilih sebagai media bermain terapeutik selama anak usia prasekolah menjalani perawatan di rumah sakit adalah mengurangi dampak hospitalisasi akibat prosedur keperawatan karena permainan ini tidak memerlukan energi yang besar dan mudah, sehingga dalam menyelesaikan sesuatu lambat laun mental anak juga terbiasa untuk bersikap tenang, sabar dan tekun. ${ }^{7}$

Hasil dari studi pendahuluan yang dilakukan pada bulan Februari 2019 oleh peneliti, dilakukan pengamatan dan penilaian kecemasan anak dengan menggunakan skala Hamilton Rating Scale For Anxiety (HARS) pada ruang rawat inap anak kepada 10 anak usia prasekolah (4 sampai dengan 6 tahun) didapatkan hasil 2 dari 10 anak yang artinya $20 \%$ anak mengalami kecemasan ringan ditandai menangis saat ditinggal orang tua pergi. Saat dilakukan tindakan pemasangan infus anak memegang erat orang tua dan 6 dari 10 anak yang artinya $60 \%$ anak mengalami kecemasan sedang saat dirawat di rumah sakit ditandai dengan anak susah tidur. Anak takut kepada petugas kesehatan yang berpakaian putih 2 dari 10 anak yang artinya 20\% anak mengalami kecemasan berat, dimana jika akan dilakukan tindakan pengobatan anak terlihat memegangi kuat dan histeris sehingga pulang paksa adalah keputusan yang diambil orang tua dikarenakan orang tua panik. Hasil wawancara yang dilakukan peneliti dengan kepala ruangan anak didapatkan bahwa belum ada program terapi bermain yang khusus dilakukan oleh petugas kesehatan di Rumah Sakit dalam menangani kecemasan anak selama menjalani perawatan.

Berdasarkan data diatas, maka penulis tertarik untuk mengadakan penelitian tentang pengaruh terapi bermain (puzzle) terhadap kecemasan anak usia prasekolah (4-6 tahun) yang mengalami hospitalisasi di ruang anak Runiah Sakit Umum Daerah Pringsewu

Penelitian Hasim et all pengaruh terapi bermain puzzle terhadap kecemasan anak usia prasekolah yang mengalami hospitalisasi di Ruang Cendana RSUD Sleman Yogyakarta. Hasil uji statistic didapatkan ada perbedaan yang bermakna antara tingkat kecemasan anak usia prasekolah sebelum dan sesudah pemberian terapi bermain yang dilihat dari nilai thitung > t tabel $(4,000>1,699)$, yang berarti $\mathrm{HO}$ ditolak dan $\mathrm{H} 1$ diterima, dengan taraf signifikansi $\mathrm{p}=0,000$ yang menunjukkan bahwa nilai $\mathrm{p}<0,05$. Berdasarkan dari hasil penelitian tersebut diharapkan dapat dijadikan sebagai 
acuan dalam melakukan intervensi terapi bermain pada anak yang mengalami hospitalisasi khususnya anak usia prasekolah dalam mengatasi kecemasan sebagai suatu respon hospitalisasi.

Penelitian Fitriani,Santi,Rahmayanti (2017) terapi bermain puzzle terhadap penurunan tingkat kecemasan pada anak usia prasekolah (3 sampai dengan 6 tahun) di ruang Hematologi Onkologi yang menjalani kemoterapi. Hasil penelitian menggunakan wilcoxon sign rank test didapatkan p-value 0,005 menunjukkan bahwa terapi bermain puzzle memberikan pengaruh terhadap penurunan tingkat kecemasan pada anak usia prasekolah yang menjalani kemoterapi di ruang Hematologi Onkologi Anak RSUD Ulin Banjarmasin. Terapi bermain menggunakan puzzle dapat disarankan sebagai salah satu terapi bermain untuk menurunkan tingkat kecemasan.

\section{METODE}

Variable Independen yaitu Terapi bermain dan variable dependen (terikat) disebut juga variable akibat, variable dependen dalam penelitian ini yaitu Kecemasan. ${ }^{10}$. Populasinya terdiri anak yang usia 4 sampai dengan 6 tahun yang dirawat di ruang anak, besaran populasi 16 dengan menggunakan teknik total populasi. Alat ukur yang digunakan dalam penelitian ini adalah kuesioner dan lembar SOP Terapi Bermain. Alat pengumpulan data terdiri dari kuesioner berisi pertanyaan mengenai data demografi anak dan megenai kecemasan dengan 14 komponen pertanyaan yang mungkin dialami oleh anak (Kuesioner HARS). Uji statistik adalah uji T-test yaitu uji beda dua mean dependent (paired sampel T test).

\section{HASIL}

Karakteristik Responden (Usia, Jenis Kelamin, Pendidikan Ibu, Penghasilan Orang Tua)

Tabel 1

Distribusi frekuensi Karakteristik Anak Usia Prasekolah (4 sampai dengan 6 Tahun) Yang Mengalami Hospitalisasi Di Ruang Anak

\begin{tabular}{|c|c|c|c|}
\hline Variabel & Kategori & Frequency & \% \\
\hline \multirow{4}{*}{ Umur } & 4 & 7 & 43,8 \\
\cline { 2 - 4 } & 5 & 5 & 31,2 \\
\cline { 2 - 4 } & 6 & 4 & 25 \\
\cline { 2 - 4 } & Total & 16 & 100,0 \\
\hline \multirow{2}{*}{$\begin{array}{c}\text { Jenis } \\
\text { Kelamin }\end{array}$} & Perempuan & 9 & 56,3 \\
\cline { 2 - 4 } & laki-laki & 7 & 43,7 \\
\cline { 2 - 4 } & Total & 16 & 100,0 \\
\hline \multirow{4}{*}{$\begin{array}{c}\text { Pendidikan } \\
\text { Ibu }\end{array}$} & SD & 2 & 12,5 \\
\cline { 2 - 4 } & SMP & 4 & 25 \\
\cline { 2 - 4 } & SMA & 6 & 37,5 \\
\cline { 2 - 4 } & Sarjana & 4 & 25 \\
\cline { 2 - 4 } & Total & 16 & 100,0 \\
\hline \multirow{3}{*}{$\begin{array}{c}\text { Penghasilan } \\
\text { Keluarga } \\
\text { Perbulan }\end{array}$} & $2,432,001$ & 10 & 62,5 \\
\cline { 2 - 4 } & $>\mathrm{Rp}$ & 6 & 37,5 \\
\cline { 2 - 4 } & $2,432,001$ & & \\
\cline { 2 - 4 } & Total & 16 & 100,0 \\
\hline
\end{tabular}

Berdasarkan tabel 1 di atas dapat dilihat bahwa sebagian besar responden berusia 4 tahun sebanyak $43,8 \%$, jenis kelamin perempuan sebanyak 56,3\%, Pendidikan Ibu 37,5\% sekolah menengah atas, penghasilan keluarga perbulan, dan $\mathrm{Rp}<2,432,001$ sebanyak $62,5 \%$.

\section{Analisis Univariat}

Variabel tingkat kecemasan sebelum tekhnik puzzle

\section{Tabel 2}

\begin{tabular}{|c|c|c|c|c|c|c|}
\hline \multicolumn{7}{|c|}{$\begin{array}{c}\text { Rata-rata tingkat kecemasan Anak Usi } \\
\text { Prasekolah (4-6 Tahun) Yang Mengalar } \\
\text { Hospitalisasi sebelum terapi bermain } \\
\text { (puzzle) }\end{array}$} \\
\hline $\begin{array}{l}\text { Pembe } \\
\text { rian } \\
\text { interve } \\
\text { nsi }\end{array}$ & $\mathrm{N}$ & Mean & $\begin{array}{l}\text { Min } \\
\text { imal }\end{array}$ & $\begin{array}{l}\text { Max } \\
\text { imal }\end{array}$ & $\begin{array}{l}\mathrm{S} \\
\mathrm{D}\end{array}$ & $\begin{array}{l}95 \\
\% \\
\text { CI }\end{array}$ \\
\hline $\begin{array}{l}\text { Sebelu } \\
\text { m } \\
\text { terapi }\end{array}$ & 16 & $\begin{array}{c}20,9 \\
4\end{array}$ & 16 & 26 & $\begin{array}{l}2, \\
5 \\
4 \\
2\end{array}$ & $\begin{array}{l}10, \\
53- \\
11, \\
68\end{array}$ \\
\hline
\end{tabular}

Berdasarkan tabel 2 diatas diketahui nilai ratarata (mean) pada anak usia prasekolah tingkat kecemasan akibat hospitalisasi sebelum pemberian intervensi 20,94 dengan tingkat kecemasan minimal 16 poin dan maximal 26 poin. 


\section{Variabel tingkat kecemasan setelah tekhnik puzzle}

Tabel 3

\section{Rata-rata tingkat kecemasan Anak Usia Prasekolah (4 sampai dengan 6 Tahun) Yang Mengalami Hospitalisasi setelah terapi bermain (puzzle)}

\begin{tabular}{ccccccc}
\hline $\begin{array}{c}\text { Pemberi } \\
\text { an } \\
\begin{array}{c}\text { interven } \\
\text { si }\end{array}\end{array}$ & N Mean & $\begin{array}{c}\text { Min } \\
\text { ima } \\
1\end{array}$ & $\begin{array}{c}\text { Ma } \\
\text { xim } \\
\text { al }\end{array}$ & SD & $\begin{array}{c}95 \\
\% \\
\text { CI }\end{array}$ \\
\hline $\begin{array}{c}\text { Setelah } \\
\text { terapi }\end{array}$ & 16 & $\begin{array}{c}13,3 \\
8\end{array}$ & 8 & 19 & 2,47 & 7,77 \\
& & & & & 3 & - \\
& & & & & 8,49 \\
\hline
\end{tabular}

Berdasarkan tabel 2 diatas diketahui nilai ratarata (mean) pada anak usia prasekolah tingkat kecemasan akibat hospitalisasi setelah pemberian intervensi 13,38 dengan tingkat kecemasan minimal 8 poin dan maksimal 19 poin.

\section{Analisis Bivariat}

\section{Pengaruh Terapi bermain}

Analisis yang dilakukan untuk mengetahui pengaruh terapi bermain terhadap tingkat kecemasan akhibat hospitalisasi pada anak usia prasekolah di ruang perawatan anak RSUD Kabupaten Pringsewu dengan menggunakan uji statistik $\mathrm{t}$ dengan taraf kesalahan nilai $\alpha<0,05$ kemudian diprogram dengan sistem komputer menggunakan program SPSS for windows.

Tabel 4

Pengaruh Terapi Bermain (Puzzle)

Terhadap Kecemasan Anak Usia

Prasekolah (4-6 Tahun) Yang Mengalami Hospitalisasi Di Ruang Anak yang berarti adanya pengaruh terapi bermain terhadap tingkat kecemasan akibat hospitalisasi pada anak usia prasekolah di ruang anak.

\section{PEMBAHASAN}

\section{Karakteristik Responden}

Berdasarkan tabel 1 di atas dapat dilihat bahwa sebagian besar responden berusia 4 tahun sebanyak 43,8\%, jenis kelamin perempuan sebanyak 56,3\%, Pendidikan Ibu 37,5\% sekolah menengah atas, dan penghasilan keluarga perbulan, $\mathrm{Rp}<2,432,001$ sebanyak $62,5 \%$.

Pada hasil penelitian didapatkan usia anak terbanyak yang menjadi responden adalah usia 4-6 tahun dimana jumlah terbanyak yakni usia 4 tahun sebanyak $43,8 \%$, hal ini dikarenakan kelompok usia 0-5 tahun merupakan kelompok usia yang paling tinggi insiden penyakit seperti pneumonia karena Anak kelompok usia 0-5 tahun lebih rentan terhadap penyakit karena imunitas yang belum sempurna, saluran pernapasan yang cukup sempit serta tingginya prevalensi kolonisasi bakteri patogen di nasofaring. Begitu juga pada penyakit diare dan lainnya yang menyebabkan anak usia lebih muda lebih banyak kejadian rawat.

Anak balita lebih rentan menderita penyakit infeksi karena sudah mulai bergerak aktif untuk bermain, sehingga sangat mudah terkontaminasi oleh kotoran. bahwa anak usia 2-5 tahun sudah mulai memiliki kebiasaan membeli makanan jajanan yang belum tentu terjaga kebersihannya, baik dalam pengolahan maupun penyajiannya, sehingga sangat mudah P-terkontaminasi oleh kuman sehingga mudah

\begin{tabular}{ccccc}
\hline Kelompok & $\mathrm{N}$ & $\begin{array}{c}\text { Beda } \\
\text { Mean }\end{array}$ & SD & $\begin{array}{c}\text { Std. Eror } \\
\text { mean }\end{array}$ \\
\hline $\begin{array}{c}\text { Sebelum } \\
\text { terapi }\end{array}$ & 16 & 7,563 & $\begin{array}{c}2,1 \\
31\end{array}$ & 0,598 \\
Setelah terapi & & & & \\
\hline
\end{tabular}

Diperoleh $\mathrm{t}$ tabel 12,638 dan $\mathrm{t}$ hitung 1,746 berdasarkan hasil analisis uji bivariat pada tabel 4. Selanjutnya berdasarkan hasil uji statistik didapatkan $p$-value $=0,000(\mathrm{p}$-value $<\alpha=0,05)$
Valuterkena penyakit dengan demikian menjadi lebih banyak jumlah anak balita muda rawat 0,00 djbandingkan dengan usia yang lebih tua. ${ }^{11}$

Anak prasekolah adalah mereka yang berusia antara dua sampai lima tahun. Pribadi yang mempunyai berbagai macam potensi adalah anak prasekolah . Potensi- potensi itu dikembangkan dan dirangsang agar pribadi 
anak tersebut berkembang secara optimal. Masa pra sekolah menurut Munandar merupakan masa - masa untuk bermain dan mulai memasuki masa taman kanak - kanak. Waktu bermain merupakan sarana untuk tumbuh dalam lingkungan dan kesiapan dalam belajar formal ${ }^{11}$.

Kecemasan akan sangat berpengaruh pada anak - anak usia prasekolah, Bagi anak, sakit dan dirawat di rumah sakit oleh karena suatu alasan yang berencana atau darurat, mengharuskan anak untuk tinggal di rumah sakit, menjalani terapi dan perawatan sampai pemulangannya kembali ke rumah merupakan krisis utama yang tampak pada anak. ${ }^{11}$

Karakteristik anak rawat usia prasekolah di ruang anak RSUD Kabupaten Pringsewu jenis dengan jenis kelamin perempuan sebanyak $56,3 \%$, hasil pada penelitian ini tidak sesuai dengan teori yang mengungkapkan bahwa kemungkinan anak dengan jenis kelamin lakilaki lebih banyak terpapar di luar rumah sehingga besar kemungkinan untuk terinfeksi kuman penyakit., dibandingkan dengan anak balita jenis kelamin perempuan anak balita jenis kelamin laki-laki untuk terkena penyakit infeksi yang mengakibatkan rawat inap di rumah sakit memiliki risiko lebih besar ${ }^{12}$.

Hasil penelitian jenis kelamin dapat mempengaruhi kecemasan dan stress pada anak, dimana anak perempuan pra sekolah yang menjalani hospitalisasi memiliki tingkat kecemasan yang lebih tinggi dibandingkan lakilaki. Oedipus artinya anak laki-laki akan dekat dengan ibunya atau sebaliknya anak perempuan lebih dekat dengan ibunya. Responden dalam penelitian ini didominasi oleh anak laki-laki dan sebagian besar selama perawatan anak didampingi oleh ibunya ${ }^{11}$.

Pendidikan Ibu 37,5\% sekolah menengah atas, dan penghasilan keluarga perbulan, $\mathrm{Rp}<$ $2,432,001$ sebanyak $62,5 \%$. Orang tua yang mendapatkan mengikuti kursus untuk mengasuh anak dan memiliki pendidikan lebih akan menggunakan teknik pengasuhan authoritative dibandingkan dengan orang tua yang tidak mendapatkan pelatihan dalam mengasuh anak dan pedidikan sehingga dapat lebih menjaga kesehatan anak dan orang tua dari kelas rendah dan menengah cenderung lebih keras, mamaksa dan toleran dibandingkan dengan orang tua dari kelas atas.

Ketika ada masalah kesehatan pada anaknya respon kecemasan orang tua merupakan hal yang paling umum yang dialami, karena anak adalah bagian dari kehidupan orang tuanya sehingga apabila ada pengalaman yang menganggu kehidupan anak maka orang tua pun merasa stress atau cemas. ${ }^{13}$

Kecemasan orang tua dapat dipengaruhi oleh beberapa hal, salah satu diantaranya yaitu lama hari anak dirawat. Lama hari anak dirawat dapat dinilai dan diukur, kondisi medis pasien atau adanya infeksi nosokomial menyebabkan lama hari rawat yang memanjang. ${ }^{12}$

\section{Pengaruh Terapi Bermain (Puzzle) Terhadap Kecemasan Anak Usia Prasekolah (4-6 Tahun) Yang Mengalami Hospitalisasi Di Ruang Anak}

Dapat disimpulkan bahwa ada pengaruh bermain Puzzle terhadap tingkat kecemasan akhibat hospitalisasi pada anak usia prasekolah di ruang perawatan anak RSUD Kabupaten Pringsewu. Hal ini menunjukkan bahwa dengan diberikan terapi bermain dengan tekhnik puzzle, rata-rata anak akan cenderung mengalami penurunan tingkat kecemasan yang lebih banyak dibandingkan dengan anak yang tidak mendapat perlakuan berupa tekhnik bermain dengan puzzle.

Sejalan dengan teori menurut (Wong,2008) Bermain merupakan cerminan, intelektual, kemapuan fisik, emosional dan sosial dan media yang baik untuk belajar adalah bermain karena dengan bermain anak-anak akan belajar menyesuaikan diri dengan lingkungan, berkata- 
kata (berkomunikasi), melakukan apa yang dapat dilakukannya, dan mengenal jarak, waktu serta suara ${ }^{1}$. Menurut Hamalik Puzzle memberikan kesempatan untuk belajar, menarik minat anak dan membina semangat belajar dalam bermain. Permainan puzzle dapat dilakukan di rumah dan di sekolah yang diberikan oleh guru. Puzzle merupakan suatu metode yang dimana menyusun potonganpotongan gambar menjadi gambar yang utuh. Gambar adalah sesuatu yang diwujudkan secara visual dalam bentuk dua dimensi sebagai curahan perasaan dan pikiran ${ }^{14}$.

Bermain merupakan hal yang menyenangkan bagi anak-anak. Permainan terapeutik (therapeutic play) ini menyenangkan anakanak, dimana sifat permainan terapeutik ini merupakan permainan yang sederhana, dan sebagai upaya mekanisme peristiwa dan perkembangan yang kritis seperti hospitalisasi. Permainan terapeutik ini terdiri dari aktivitasaktivitas yang tergantung dengan kebutuhan perkembangan lingkungan maupun anak, dan dapat disampaikan dalam berbagai bentuk di antaranya adalah pertunjukan wayang interaktif, seni ekspresi atau kreatif, permainan boneka atau puzzle dan lain-lain yang berorientasi untuk pengobatan. Tujuan bermain pada dasarnya untuk memperoleh kesenangan, anak usia prasekolah tidak merasa jenuh serta mengakibatkan kecemasan akan dilupakan. Bermain terapeutik diyakini memiliki efek healing atau penyembuhan dengan sifat katarsis atau pelepasan kecemasan sehingga menjadikan bermain berkembang menjadi sebuah metode terapi pada anak. Jenis permainan pada anak usia prasekolah yang menggunakan kemampuan motorik atau skill play yang banyak dipilih yaitu seperti lilin yang dapat dibentuk, menggambar manikmanik ukuran besar, dan puzzle .

Perawatan dirumah sakit membuat anak menjadi stres atau tertekan. Sebagai akibatnya, anak merasa gugup dan tidak tenang, bahkan pada saat menjelang tidur. Anak sering merasa terkekang selama dirawat di rumah sakit. Hal ini disebabkan adanya pembatasan aktivitas anak sehingga anak merasa kehilangan kekuatan diri. Perawatan di rumah sakit sering kali dipersepsikan sebagai hukuman sehingga anak akan merasa malu, bersalah, dan cemas atau takut. Anak yang sangat cemas dapat bereaksi agresif dengan marah dan berontak ${ }^{15}$.

Kecemasan pada anak biasanya muncul karena berbagai perubahan yang muncul di sekelilingnya, baik fisik maupun emosional. Dapat juga akibat kurangnya support system yang ada di sekitarnya. Sedangkan gejala klinis kecemasan yang sering ditemukan pada anak adalah perasaan cemas, kekhawatiran, dan mudah tersinggung ${ }^{15}$.

Selain itu, pada anak yang mengalami kecemasan, dalam kesehariannya terlihat tidak tenang, konsentrasi menurun, adanya perubahan pola tingkah laku dalam kesehariannya, bahkan hingga dapat menyebabkan gangguan pola tidur. Anak yang mengalami kecemasan akan memunculkan respon fisologis, seperti perubahan pada sistem kardiovaskuler, perubahan pola nafas yang semakin cepat atau terengah-engah. Selain itu, dapat pula terjadi perubahan pada sistem pencernaan dan neuromuscular seperti nafsu makan menurun, gugup, tremor, hingga pusing dan insomnia. Kulit mengeluarkan keringat dingin dan wajah menjadi kemerahan. Selain respon fisiologis, biasanya anak juga akan menampakkan respon perilaku, seperti gelisah, ketegangan fisik, tremor atau gemetar, reaksi kaget, bicara cepat, menghindar, hingga menarik diri dari hubungan interpersonal ${ }^{15}$.

Respon kognitif yang mungkin muncul adalah perhatian terganggu, pelupa, salah dalam memberikan penilaian, hambatan berpikir, tidak mampu berkonsentrasi, dan ketakutan. Sedangkan respon afektif yang biasa muncul adalah tidak sabar, tegang, dan waspada ${ }^{16}$. 
Penelitian dengan judul pengaruh terapi bermain terhadap kecemasan anak yang menjalani hospitalisasi di Ruang Mirah Delima Rumah Sakit William Booth Surabaya April 2014. Hasil penelitian diperoleh sebagian besar responden berjenis kelamin laki-laki sebanyak 18 responden (16\%), sebagian besar responden belum pernah dirawat di rumah sakit sebanyak 19 responden (71\%), sebagian responden berusia 6 tahun sebanyak 14 responden $(52 \%)$, responden terbanyak sebelum diberikan terapi bermain memiliki tingkat kecemasan Oversensitivity sebanyak 15 responden (55\%) dan setelah diberikan terapi bermain didapatkan 13 orang mengalami perubahan/penurunan skor/skala. Berdasarkan uji statistik terdapat pengaruh terapi bermain dengan kecemasan, dengan tingkat kesignifikansinya 0,000 dimana $\rho<0,05$.

Penelitian Kaluas dengan judul perbedaan terapi bermain puzzle dan bercerita terhadap kecemasan anak usia prasekolah (3-5 tahun) selama hospitalisasi di ruang anak RS.TK.III R.W.Mongisidi Manado. Metode Penelitian menggunakan quasi experimental design dengan rancangan perbandingan kelompok statis.Hasil penelitian didapatkan nilai $p$ value $=0,000<\alpha=0,05$ (Ho ditolak). Kesimpulan yaitu ada perbedaan terapi bermain puzzle dan bercerita terhadap kecemasan anak usia prasekolah (3-5 tahun) selama hospitalisasi di ruang anak RS.TK.III R.W. Mongisidi Manado $^{2}$.

Penelitian Fitriani dkk terpai bermain puzzle terhadap penurunan tingkat kecemasan pada anak usia prasekolah (4-6 tahun) yang menjalani kemoterapi di ruang Hematologi Onkologi Anak. Hasil penelitian menggunakan wilcoxon sign rank test didapatkan p-value 0,005 menunjukkan bahwa terapi bermain puzzle memberikan pengaruh terhadap penurunan tingkat kecemasan pada anak usia prasekolah yang menjalani kemoterapi di ruang Hematologi Onkologi Anak RSUD Ulin Banjarmasin. Terapi bermain menggunakan puzzle dapat disarankan sebagai salah satu terapi bermain untuk menurunkan tingkat kecemasan. Menurut peneliti pada saat dirawat di rumah sakit, anak akan mengalami berbagai perasaan yang sangat tidak menyenangkan, seperti marah, takut, cemas, sedih, dan nyeri. Perasaan tersebut merupakan dampak dari hospitalisasi yang dialami anak karena menghadapi beberapa stressor yang ada dilingkungan rumah sakit. Untuk itu, dengan melakukan permainan anak akan terlepas dari ketegangan dan stress yang dialaminya karena dengan melakukan permainan anak akan depat mengalihkan rasa sakitnya pada permainannya (distraksi) dan relaksasi melalui kesenangannya melakukan permainan. Dengan demikian, permainan merupakan media komunikasi antar anak dengan orang lain, termasuk dengan perawat atau petugas kesehatan dirumah sakit. Perawat dapat mengkaji perasaan dan pikiran anak melalui ekspresi nonverbal yang ditunjukkan selama melakukan permainan atau melalui interaksi yang ditunjukkan anak dengan orang tua dan teman kelompok bermainnya ${ }^{9}$.

Menurut peneliti dari hasil yang didapat bahwa terapi bermain dengan teknik bermain puzzle dapat menurunkan tingkat kecemasan pada anak yang dirawat dibanding dengan anak yang tidak dilakukan terapi bermain walaupun mengalami penurunan tingkat kecemasan, sehingga dapat disimpulkan dalam penelitian ini terapi bermain dengan teknik puzzle efektif dalam menurunkan tingkat kecemasan pada anak.

Setiap orang berbeda-beda begitupun dengan klien, tidak ada klien yang sama menurut peneliti. Oleh sebab itu diperlukan upaya dan teknik untuk menurunkan kecemasan klien. Pada saat penelitian kondisi ini dapat diamati dimana anak-anak prasekolah masih sangat dekat dengan kedua orangtuanya. Apabila orang tua melakukan pendekatan yang baik kepada anak maka kepercayaan responden akan cukup baik, pada saat anak masuk rumah sakit kondisi ini tidak dapat menyebabkan anak 
merasa seperti terkena hukuman. Anak tidak merasa tertekan dan merasa nyaman dengan prosedur pengobatan yang dilakukan.

Upaya penurunan kecemasan pada anak pra sekolah dirumah sakit dapat dilakukan dengan meningkatkan teknik dan keterampilan perawat dalam upaya menurunkan tingkat kecemasan kepada pasien, dimasa pendidikan kemampuan ini sebenarnya sudah dimiliki oleh perawat sehingga upaya management rumah sakit untuk meningkatkan, mengawasi dan memotivasi perawat dalam melaksanakan asuhan keperawatan sangat penting, dimana salah satunya dengan mengevaluasi dan memonitoring perawat dalam melaksanakan asuhan keperawatan.

\section{KESIMPULAN}

Berdasarkan hasil penelitian dan pembahasan diambil beberapa kesimpulan sebagai berikut

1. Sebagian besar responden berusia 4 tahun sebanyak $43,8 \%$, jenis kelamin perempuan sebanyak 56,3\%, Pendidikan Ibu 37,5\% sekolah menengah atas, penghasilan keluarga perbulan, dan $\mathrm{Rp}<2,432,001$ sebanyak $62,5 \%$.

2. Sebelum diberikan terapi bermain rata-rata tingkat kecemasan akibat hospitalisasi pada anak usia prasekolah sebelum teknik bermain puzzle adalah 20.94 .

3. Setelah diberikan terapi bermain rata-rata tingkat kecemasan akibat hospitaliisasi pada anak usia prasekolah setelah diterapkan teknik bermain puzzle adalah 13,38 .

4. Ada perbedaan kecemasan sebelum dan sesudah diberikan terapi bermain dengan selisih nilai 7,563.

\section{DAFTAR PUSTAKA}

1. Wong, Donna L. (2008).Buku Ajar KeperawatanPedeatrikvolume 1. EGC: Jakarta

2. Kaluas. (2015). Perbedaan terapi bermain puzzle dan bercerita terhadap kecemasan anak usia prasekolah (3-5 tahun) selama hospitalisasidi ruang anak RS.TK.III R.W.Mongisidi Manado. ejournal.unsrat.ac.id/index.php/jkp/article /download/7969/7527 skripsi dipublikasikan

3. Riskesdas. (2013). Ringkasan Kesehatan dasar tahun 2013. Jakarta

4. Nursalam. (2013). Manajemen Keperawatan aplikasi dlam praktik keperawatan profesional edisi 3. Salemba Medika Jakarta.

5. Adriana dian. (2011). Tumbuh Kembang dan terapi bermain pada anak. Jakarta : Salemba Medika

6. Ngastiyah. (2005). Perawatan anak sakit. EGC : Jakarta

7. Lisbet Octovia Manalu1, Budi Somantri2, Riski Renaldi Barokah3, (2018). Bermain Terapeutik Puzzle Mempengaruhi Tingkat Kecemasan Pada Anak Usia Prasekolah (36 Tahun) Sebelum Pemberian Obat Intravena (Bolus). Skripsi dipublikasikan STIKes Rajawalie-mail: lisbetpediatrik@gmail.com

8. Hasim Mariyani, Sampurno Edi, Najmuna Army, Kirnantoro (2013). Pengaruh Terapi Bermain Terhadap Tingkat Kecemasan Anak Usia Prasekolah Yang Mengalami Hospitalisasi Di Ruang Cendana Rsud Sleman Yogyakarta. http://elibrary.almaata.ac.id/124/

9. Winda Fitriani, Eka Santi, Devi Rahmayanti. (2017). Terapi Bermain Puzzle Terhadap Penurunan Tingkat Kecemasan Pada Anak Usia Prasekolah (36 Tahun) Yang Menjalani Kemoterapi Di Ruang Hematologi Onkologi Anak. Program Studi Ilmu Keperawatan Fakultas Kedokteran Universitas Lambung Mangkurat.

file:///D:/laporan\%20penelitian\%202018/fi triani.pdf

10. Dharma, Kelana K. (2011). Metodelogi Penelitian Keperawatan. Jakarta Timur: CV. Trans Info Media 
11. Madyastuti Rahayuningrum Lina dan Sipora Kusuma Dewi pessy. (2018). Visual support menurunkan kecemasan anak yang mengalami hospitalisasi pada pemberian injeksi. Http://journal.unigres.ac.id/index.php/jn c/article/view/637

12. Departemen Kesehatan RI. (2009). Pedoman Pelaksanaan Program Rumah Sakit. Sayang Ibu dan Bayi (RSSIB). Jakarta: Depkes RI

13. Mia audina, franly onibala, ferdinan wowiling. (2017). Hubungan Dampak Hospitalisasi Anak Dengan Tingkat Kecemasan Orang Tua Di Irina E Atas RSUP Prof. Dr. R. D. Kandou manado. https://ejournal.unsrat.ac.id/index.php/j kp/article/view/14885

14. Hamalik, Oemar, 2004, Proses Belajar Mengajar. Jakarta : Bumi Aksara

15. Hawari, Dadang. (2011). Manajemen Stress, Cemas dan Depresi.Jakarta :Fakultas Kedokteran Universitas Indonesia

16. Stuart, G.W.,\& Sundeen, S.J. (2013). Buku saku keperawatan jiwa. EGC: Jakarta

17. Hale. (2014). Pengaruh terapi bermain terhadap kecemasan anak yang menjalani hospitalisasi di Ruang Mirah Delima Rumah Sakit William Booth Surabaya April 2014. skripsi dipublikasikan 
Wacana Kesehatan Vol. 6, No. 1, Juli 2021 